\title{
The Role of Outer Membrane Proteins in the Survival of Neisseria gonorrhoeae P9 within Guinea-pig Subcutaneous Chambers
}

\author{
By H. M. MCBRIDE, P. R. LAMBDEN, J. E. HECKELS* AND \\ P. J. W A T T \\ Department of Microbiology, Southampton University Medical School, Southampton \\ General Hospital, Tremona Road, Southampton SO9 4XY, U.K.
}

(Received 11 December 1980; revised 18 February 1981)

\begin{abstract}
Guinea-pig subcutaneous chambers were infected with a mixture of gonococcal variants of defined outer membrane protein profile. Survival within the chambers was a two-stage process. The initial advantage conferred by the lack of opacity-related outer membrane protein was transient and survivors were replaced by opaque colonial variants. Amongst these survivors were variants which produced opacity-related proteins (IId, IIe and IIf) not present in the initial inoculum. Thus, outer membrane protein composition is an important factor in survival in vivo.
\end{abstract}

\section{INTRODUCTION}

The use of the guinea-pig chamber as a model for the study of gonococcal infection has received considerable attention over several years. In particular, it has been used to apply a selection pressure in order to obtain in vivo-grown gonococci (Penn et al., 1976). Such organisms have been shown by immunoelectrophoresis to possess antigens not expressed on laboratory-grown gonococci of the same strain (Penn et al., 1978). A possible implication is that antigens selected for by growth in vivo play a role in the pathogenesis of gonorrhoea.

Recent studies using defined opacity types of gonococci have shown that considerable surface protein variations are possible within a single strain (Lambden \& Heckels, 1979; Swanson, $1978 b$ ) and that external pressures may result in the selection of phenotypes which are adapted to a particular environment (James \& Swanson, 1977). By analogy, the variations apparently induced by growth in guinea-pig chambers may be the result of the selection of particular colonial opacity variants present in the initial inoculum. This would be in accord with the observations that some variants have altered resistance to host defence systems, including complement-mediated serum killing (Lambden et al., 1979), leukocyte association (King \& Swanson, 1978) or the effect of proteolytic enzymes (Swanson, 1978a), which should confer an advantage for survival in guinea-pig chambers.

In strain P9 we have obtained a number of colonial variants with defined differences in outer membrane protein composition which can be correlated with differences in virulence-related properties (Lambden et al., 1979). One protein, the major outer membrane protein (protein I), is present in all colonial variants studied, while opaque colonial types produce one or more of a range of additional outer membrane proteins (II, IIa, IIb, IIc, IId) in the molecular weight range 29000-27500. We have used these variants with defined differences in surface composition in order to study the selection of particular phenotypes in the guinea-pig chamber model.

\section{METHODS}

Bacterial strains and growth conditions. Colonial variants of Neisseria gonorrhoeae strain P9 (Table 1) were grown on clear typing medium as previously described (Lambden et al., 1979). 
Table 1. Variants of $N$. gonorrhoeae P9 used

$\begin{array}{ccc}\text { Variant } & \begin{array}{c}\text { Outer membrane protein profile } \\ \text { and colony morphology* }\end{array} \\ 1 & \text { I } & \mathrm{O}^{-} \mathbf{P}^{-} \\ 2 & \text { I } & \mathrm{O}^{-} \mathbf{P}^{+} \\ 13 & \text { I, IIa } & \mathrm{O}^{+} \mathrm{P}^{-} \\ 16 & \text { I, IIb } & \mathrm{O}^{+} \mathbf{P}^{-} \\ 19 & \text { I, II, IIc } & \mathrm{O}^{+} \mathbf{P}^{-} \\ 20 & \text { I, II } & \mathrm{O}^{+} \mathbf{P}^{+} \\ & \end{array}$

Implantation of subcutaneous guinea-pig chambers. Chambers were prepared by cutting 2 ml polypropylene ampoules (Sterilin, Teddington, Middx.) to give a $3 \mathrm{~cm}$ cylinder with open ends. The chambers were sterilized by autoclaving at $121^{\circ} \mathrm{C}$ for $15 \mathrm{~min}$, and two chambers were implanted under the skin of each of five guinea-pigs (Dunkin-Hartley strain, approx. $600 \mathrm{~g}$ ) according to the procedure of Veale et al. (1974). The chambers were left for $60 \mathrm{~d}$ to encapsulate.

Inoculation of chambers. Encapsulated chambers were infected with a standardized suspension of the mixture of gonococcal variants shown in Table 1 . Suspensions of each variant were first gently mixed and centrifuged at $150 \mathrm{~g}$ for $1 \mathrm{~min}$ to remove gonococcal aggregates, then diluted to give an $A_{550}$ of 1.0 corresponding to a concentration of about $2.8 \times 10^{8}$ colony-forming units (c.f.u.) per $\mathrm{ml}$ (Lambden et al., 1979). Equal volumes of each suspension were mixed and $0.5 \mathrm{ml}$ of the mixture was injected into each of the chambers.

Sampling of chambers and differential colony counting. On the day following inoculation and at regular intervals thereafter samples $(0.3 \mathrm{ml})$ were removed from the chamber. A sample of the fluid $(10 \mu \mathrm{l})$ was plated directly on to typing agar so that the relative proportion of each colonial variant present in the chamber could be determined. Samples were serially diluted in proteose peptone and plated on to typing medium to determine the total number of viable organisms in each chamber.

In vivo grown-organisms were subcultured once in order to obtain sufficient material for examination of the outer membrane protein composition. Samples of the chamber fluid were cultured on typing medium and the organisms obtained were used for sodium dodecyl sulphate-polyacrylamide gel electrophoresis (SDS-PAGE) on linear gradients of $10-25 \%(\mathrm{w} / \mathrm{v})$ acrylamide as previously described (Lambden et al., 1979). The presence of particular outer membrane proteins was confirmed by running the appropriate variant of defined outer membrane composition. The outer membrane location of new proteins was established by SDS-PAGE of a crude outer membrane preparation obtained after subjecting a gonococcal suspension to mild shearing by several rapid passages through a 21-gauge needle followed by centrifugation at $10000 \mathrm{~g}$ to remove intact bacteria (Lambden \& Heckels, 1979).

\section{RE S ULT S}

\section{Survival of organisms in guinea-pig chambers}

Subcutaneous guinea-pig chambers were inoculated with a mixture of defined colonial variants of Neisseria gonorrhoeae P9 (Table 1) such that approximately equal numbers of the variants were present at the start of the experiment. The survival of different colonial variants within the chambers is shown in Fig. 1. The behaviour in each chamber was qualitatively the same up to day 4 in that non-pilated organisms and opaque, pilated organisms were rapidly removed from the chambers, whilst transparent, pilated organisms survived relatively well. Non-pilated organisms were removed permanently and were totally replaced by pilated variants. In addition, by day 3 the proportion of opaque, pilated organisms began to increase. The sequence of events in each chamber then showed a consistent pattern although the time scale differed between individual chambers. After day 4, transparent, pilated organisms began to be eliminated from the chambers and were replaced by opaque, pilated variants until finally (by day 45) the infections had subsided and no further organisms of any opacity type could be recovered from the chambers.

\section{Identification of outer membrane proteins present in chamber-selected organisms}

The final isolate obtained from each individual chamber before the infection died out was cultured once and the organisms obtained were subjected to SDS gradient PAGE. The only 


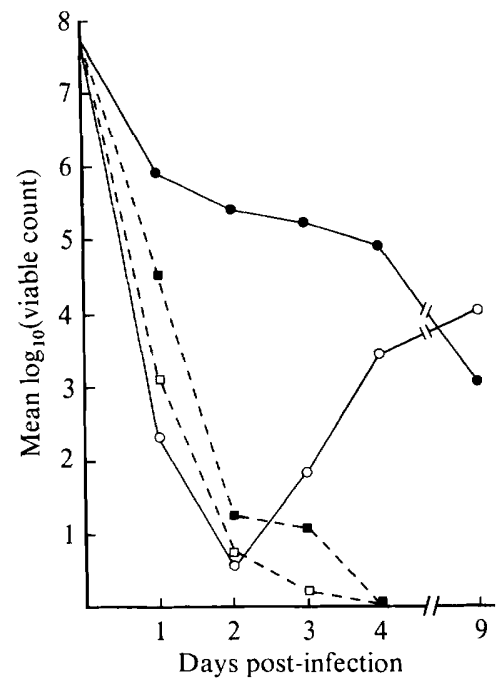

Fig. 1. Survival of colonial types immediately following mixed infection of chambers. The viable count of each colonial type in each chamber was determined as described in Methods: 0 , transparent pilated $\left(\mathrm{O}^{-} \mathrm{P}^{+}\right) ; \mathrm{O}$, opaque pilated $\left(\mathrm{O}^{+} \mathrm{P}^{+}\right) ; \mathbf{Q}$, transparent non-pilated $\left(\mathrm{O}^{-} \mathrm{P}^{-}\right) ; \square$, opaque non-pilated $\left(\mathrm{O}^{+} \mathrm{P}^{-}\right)$. Error bars have been omitted for the sake of clarity but the standard deviation of each point was between 0.5 and $1.0 \mathrm{log}$ unit.

differences noted were in the region of the opacity-related proteins, although the patterns varied greatly from chamber to chamber (Fig. 2). Amongst the organisms isolated were several variants with opacity proteins IId and IIe not present in the initial challenge (Fig. 2). In addition, a previously unknown outer membrane protein (IIf) was identified after subculture of a minority opaque colony type present among the transparent types from one of the chambers. The molecular weight of protein IIf was found to be 28300 (Fig. 3), intermediate between those of proteins IIa (28500) and IIb (28000). The outer membrane location of these proteins was confirmed by their presence in outer envelope bleb material obtained by mechanical shearing of the organisms.

On further examination of the organisms from chamber 2 (proteins IId and IIe) approximately equal numbers of two very similar opacity types were identified and purified by repeated single colony isolation. The protein profile of these two variants (Fig. 4) showed that each produced a single opacity-related protein, illustrating the importance of careful colony typing of the organisms obtained.

\section{DISCUSSION}

We have used the guinea-pig model of gonococcal infection in an attempt to mimic the environmental conditions facing invading gonococci in the natural infection in order to establish whether defined differences in surface structure influence survival. Results from each chamber suggested that a two-stage process occurred. Only pilated gonococci persisted within the chambers, but the initial selective advantage conferred by the absence of opacity-related proteins was short lasting and eventually opaque, pilated forms predominated. The factors affecting survival within the chambers are obviously complex. Both polymorphonuclear leukocytes and their lysosomal enzymes are present in chamber fluid (Novotny et al., 1977), and thus the resistance of transparent variants to the action of proteolytic enzymes (Swanson, 1978a) together with the ability of pili to inhibit phagocytosis (Denson \& Mandell, 1978) may account for the initial selection. The eventual appearance of opaque variants perhaps demonstrates a subsequent selection pressure generated by a specific 


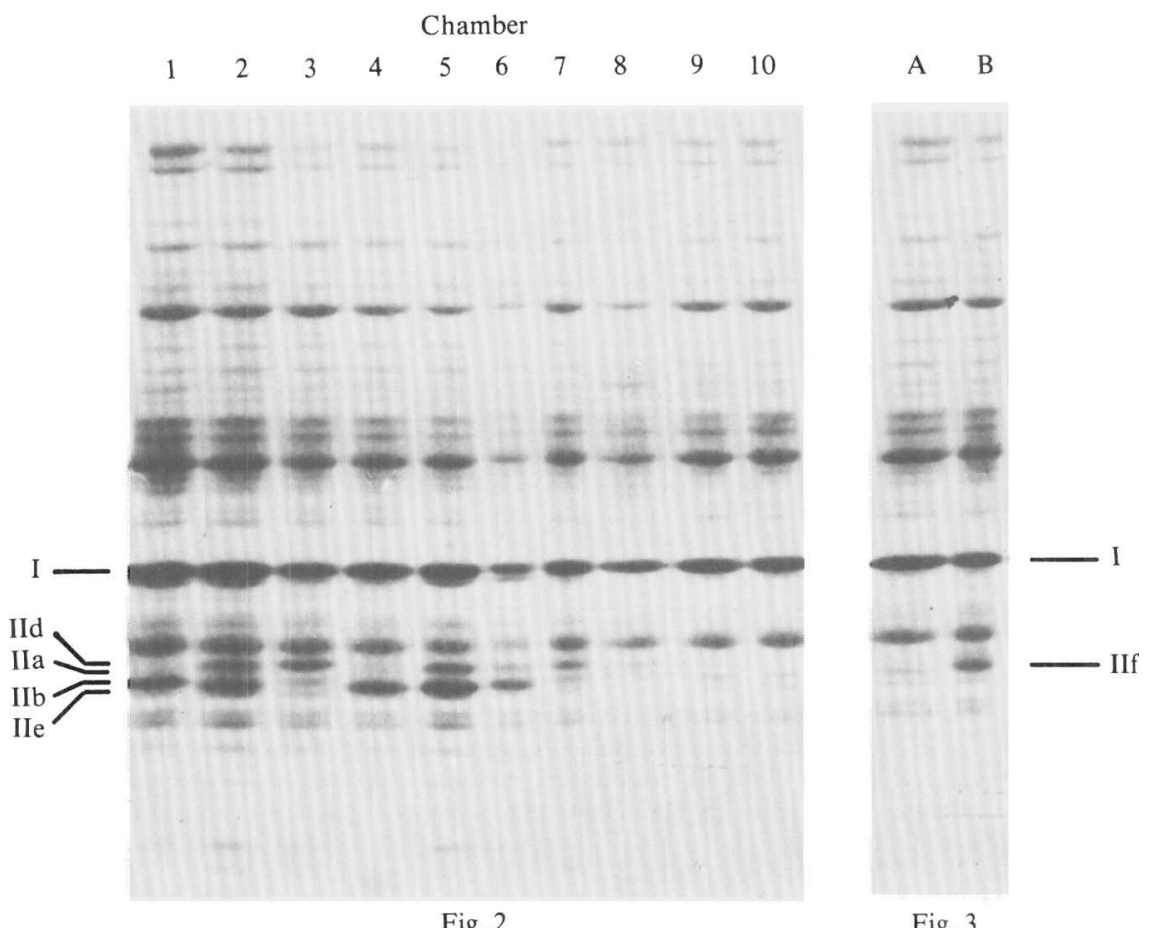

Fig. 2

Fig. 3

Fig. 2. SDS gradient PAGE of organisms taken from each guinea-pig chamber. Each track shows the polypeptide pattern for organisms isolated from a different chamber. The major opacity-related outer membrane proteins identified were: chamber 1 (day 17), protein Ilb; 2 (day 9), IId and IIe; 3 (day 45), IId; 4 (day 22), IIe; 5 (day 9), IIa and IIe; 6 (day 9), IIa and IIe; 7 (day 22), IIa; chambers 8 (day 22), 9 (day 22) and 10 (day 45), no detectable opacity protein. Isolates from all chambers gave rise to the outer membrane protein I.

Fig. 3. SDS gradient PAGE showing the identification of protein IIf. Track A, transparent colonial type with only protein $\mathrm{I}$ in outer membranes; track B, opaque colonial variant producing protein IIf in addition to protein $\mathrm{I}$.

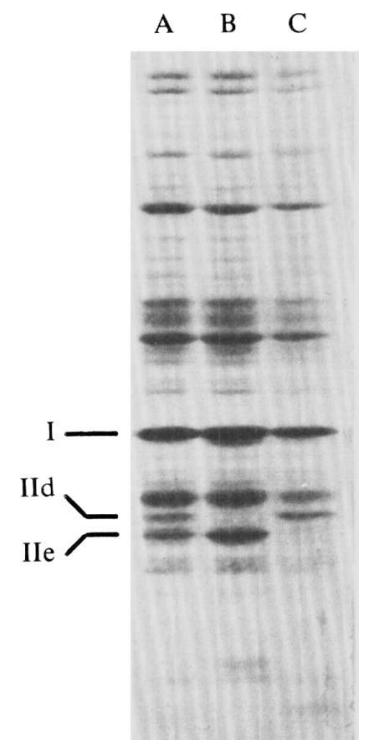

Fig. 4. SDS gradient PAGE showing the two colonial forms isolated from chamber 2. Track A, unselected culture of fluid; tracks $B$ and $C$, two clones of differing opacity obtained by selection and subculture. 
immune response to infection. This hypothesis is further supported by the occurrence in six of the ten chambers of opacity-related proteins (IId, IIe, IIf) not present in the original inoculum.

Previous studies have shown that alterations in the opacity-related proteins profoundly affect the biological properties of the organisms (Lambden et al., 1979). Thus, the selection of variants with particular opacity-related proteins is in accord with previous observations that guinea-pig chamber gonococci were antigenically distinct from the same strain grown on laboratory media (Penn et al., 1978) and showed enhanced resistance to host defences (Penn et al., 1976; Witt et al., 1976). The results from the present study demonstrate that additional, presumably antigenic, proteins are indeed present in gonococci obtained from guinea-pig chambers and that these can be maintained by careful colony typing during growth in vitro.

The ability of the gonococcus to respond to environmental pressures with a change in cell surface proteins clearly confers a biological advantage for survival since these changes markedly influence its adhesive properties and interactions with host defences. To date, we have identified seven distinct variants of outer membrane protein II in strain P9. Recent analysis has shown that there is considerable structural homology between proteins II and IIa (Heckels, 1981). The precise mechanisms controlling these structural variations, which have such an important effect on in vivo organisms, must however await detailed genetic analysis.

This work was supported by a Medical Research Council Programme Grant.

\section{REFERENCES}

Denson, P. \& Mandell, G. L. (1978). Gonococcal interactions with polymorphonuclear neutrophils; importance of the phagosome for bactericidal activity. Journal of Clinical Investigation 62, 11611171.

Heckels, J. E. (1981). Structural comparison of Neisseria gonorrhoeae outer membrane proteins. Journal of Bacteriology 145, 736-742.

James, J. F. \& Swanson, J. (1977). Studies on gonococcus infection, XIII. Occurrence of color/ opacity colonial variants in clinical cultures. Infection and Immunity 19, 332-340.

KING, G. J. \& Swanson, J. (1978). Studies on gonococcus infection, XV. Identification of surface proteins of Neisseria gonorrhoeae correlated with leukocyte association. Infection and Immunity 21, 575-584.

Lambden, P. R. \& Heckels, J. E. (1979). Outer membrane protein composition and colonial morphology of Neisseria gonorrhoeae strain P9. FEMS Microbiology Letters 5, 263-265.

Lambden, P. R., Heckels, J. E., James, L. T. \& WATT, P. J. (1979). Variations in surface protein composition associated with virulence properties in opacity types of Neisseria gonorrhoeae. Journal of General Microbiology 114, 305-312.

Novotny, P., Short, J. A., Hughes, M., Miler, J. J., SyretT, C., TURner, W. H., Harris, J . R. W. \& MacLennan, I. P. B. (1977). Studies on the mechanism of pathogenicity of Neisseria gon- orrhoeae. Journal of Medical Microbiology 10, 347-365.

Penn, C. W., Sen, D., Veale, D. R., Parsons, N. J. \& SMrth, H. (1976). Morphological, biological and antigenic properties of Neisseria gonorrhoeae adapted to growth in guinea-pig subcutaneous chambers. Journal of General Microbiology 97, 35-43.

Penn, C. W., Parsons, N. J., Veale, D. R. \& Smith, H. (1978). Correlation with different immunotypes of gonococcal antigens associated with growth in vivo. Journal of General Microbiology 105, 153-157.

SWANSON, J. (1978a). Studies on gonococcus infection, XII. Colony color and opacity variants of gonococci. Infection and Immunity 19, 320-331.

Swanson, J. $(1978 b)$. Studies on gonococcus infection, XIV. Cell wall protein differences among color/ opacity colony variants of Neisseria gonorrhoeae. Infection and Immunity 21, 292-302.

Veale, D. R., Smith, H., WitT, D. A. \& Marshall, R. B. (1974). Differential ability of colonial types of Neisseria gonorrhoeae to produce infection and an inflammatory response in sub-cutaneous perforated plastic chambers in guinea-pigs and rabbits. Journal of Medical Microbiology 8, 325-335.

Witt, K., Veale, D. R., Finch, H., Penn, C. W., Sen, D. \& SMITH, H. (1976). Resistance of Neisseria gonorrhoeae grown in vivo to ingestion and digestion by phagocytes of human blood. Journal of General Microbiology 96, 341-350. 